\title{
Cardiac function profiling and antidiabetic effect of Vigna radiata in Alloxan monohydrate induced diabetic rabbits
}

\author{
Rizwana Bilqees ${ }^{1}$, Muhammad Romman ${ }^{1 *}$, Muhammad Subhan ${ }^{2}$, Samin \\ $\mathrm{Jan}^{3}$, Rainaz Parvez ${ }^{4}$, Muhammad Adnan ${ }^{5}$, Muhammad Ikram ${ }^{6}$ and \\ Sadia Iqbal ${ }^{7}$ \\ 1. Department of Botany, University of Chitral- Pakistan \\ 2. Department of Botany, Shaheed Benazir Bhutto University, Sheringal Dir (U)-Pakistan \\ 3. Department of Botany, Islamia College Peshawar-Pakistan \\ 4. Department of Botany, Government Girls Degree College Dargai, Malakand-Pakistan \\ 5. Department of Agriculture, University of Swabi-Pakistan \\ 6. Department of Botany, Hazara University, Mansehra-Pakistan \\ 7. Department of Agriculture Chemistry University of Agriculture Peshawar-Pakistan \\ *Corresponding author's email: dr.romman@uoch.edu.pk
}

\section{Citation}

Rizwana Bilqees, Muhammad Romman, Muhammad Subhan, Samin Jan, Rainaz Parvez, Muhammad Adnan, Muhammad Ikram and Sadia Iqbal. Cardiac function profiling and antidiabetic effect of Vigna radiata in Alloxan monohydrate induced diabetic rabbits. Pure and Applied Biology. Vol. 9, Issue 1, pp390-395.

http://dx.doi.org/10.19045/bspab.2020.90043

\begin{tabular}{llll}
\hline \hline Received: 24/05/2019 & Revised: 25/07/2019 & Accepted: 05/08/2019 & Online First: 14/11/2019 \\
\hline \hline
\end{tabular}

\section{Abstract}

Diabetes mellitus is a chronic hyperglycemia associated with elevated plasma cholesterol and triglyceride levels. Natural and traditional herbal remedies are a source of new commercial products. This study aims to explore and evaluate the antidiabetic effects of Vigna radiata and its effect on triglycerides and cholesterol level. $V$. radiata extract at the dose rate of $300 \mathrm{mg} / \mathrm{kg}$ extract significantly $(\mathrm{p}<0.05)$ decreased blood glucose, triglyceride and cholesterol level at $168.66 \mathrm{mg} / \mathrm{dl}$, $72.33 \mathrm{mg} / \mathrm{dl}$ and $154 \mathrm{mg} / \mathrm{dl}$ respectively at the end of treatment with $V$. radiata extract reflecting its controlling activity of diabetic control. This study was successful to discover the active diabetes antidiabteic properties that require more deliberation in future.

Keywords: Rabbits; Cholesterol; Glucose; Triglyceride; Vignaradiate

\section{Introduction}

Diabetes mellitus is a disorder causing because of a various combined effect and ecological factors and is portrayed by depleted insulin discharge, hyperglycemia and modified uptake of lipid, sugars and proteins, added harmed $\beta$-cells of pancreas and greater danger of dilemma of vascular maladies [1]. Vigna radiata L. (Mungbean) generally named as green gram is used as laxative, also used in pregnancy and as aperients [2]. Mung beans were famous for their detoxification activities in ancient times. Mung bean tannin, protein and other polyphenols are thought to combine with organophosphorus pesticides, arsenic, 
mercury and other heavy metals enhancing the excretion of sediments from the body. Mung beans have been shown to possess antimicrobial, antioxidant and antiinflammatory activities. In addition mung beans have antihypertensive, antidiabetic, lipid metabolism accommodation, antihypertensive and antitumor effects [3]. In this study, the plant was selected for antidiabetic studies and also its effect on some kidney function tests.

\section{Materials and methods}

The plant extract was prepared in methanol solvent. Rabbits were divided in to five groups after induction of diabetes with alloxan monohydrate beside the normal group.

\section{Selection of animals}

The experimental animal selected were Rabbits (Oryctolagus cuniculus). Fifteen rabbits were purchased from local market, weighed between $1 \mathrm{~kg}$ to $2 \mathrm{~kg}$. The rabbits were maintained under standard animal house conditions for 4 weeks of acclimatization and fed on natural plant diet.

\section{Administration of extract}

Group A was kept as untreated group.i.e control group.

Group B was treated with glucophage at the dose rate of $10 \mathrm{mg} / \mathrm{kg}$ body weight.

Group $\mathrm{C}$ was treated with plant extract of Vigna radiata at dosage of $100 \mathrm{mg} / \mathrm{kg}$ body weight.

Group D was treated with Vigna radiata extract at dosage $200 \mathrm{mg} / \mathrm{kg}$ body weight.

Group E was treated with Vigna radiata extract at dosage $300 \mathrm{mg} / \mathrm{kg}$ body weight.

\section{Blood sample collection}

From the marginal veins at the back of ear, blood was obtained in Zero hours, Two hours, four hours, six hours and eight hours simultaneously and was analyzed through Double Beam UV Spectrophotometer.

\section{Results}

Group B was given Glucophage (Glibenclamide) for regular 8 hours at the interim of zero hrs, $2 \mathrm{hrs}, 4 \mathrm{hrs}, 6 \mathrm{hrs}$ and 8 hrs. At the last of the process of treatment, the glucose, triglyceride and cholesterol level of Group B was recorded as $211 \mathrm{mg} / \mathrm{dl}, 95 \mathrm{mg} / \mathrm{dl}$ and $214.66 \mathrm{mg} / \mathrm{dl}$ respectively (Table $1 \&$ Fig. 1).

Table 1. Blood glucose level $(\mathrm{mg} / \mathrm{kg})$ in alloxan induced diabetic rabbits

\begin{tabular}{|c|c|c|c|c|c|}
\hline & $\begin{array}{c}\mathbf{0} \mathbf{~ h r} \\
\text { Reading }\end{array}$ & $\begin{array}{c}\mathbf{2} \mathbf{~ h r} \\
\text { Reading }\end{array}$ & $\begin{array}{c}\mathbf{4} \mathbf{~ h r} \\
\text { Reading }\end{array}$ & $\begin{array}{c}\mathbf{6 ~ h r} \\
\text { Reading }\end{array}$ & $\begin{array}{c}\mathbf{8 ~ h r} \\
\text { Reading }\end{array}$ \\
\hline Untreated Group & 67.66 & 101 & 98.33 & 92.33 & 111.66 \\
\hline $\begin{array}{c}\text { Diabetic Control + } \\
\text { Glibenclimide (10mg/kg) }\end{array}$ & 270 & 232.33 & 220.66 & 216.66 & 211 \\
\hline $\begin{array}{c}\text { Diabetic + Methanolic } \\
\text { Extract (100mg/kg) }\end{array}$ & 336 & 332.33 & 326.66 & 318 & 315.66 \\
\hline $\begin{array}{c}\text { Diabetic + Methanolic } \\
\text { Extract (200mg/kg) }\end{array}$ & 222.33 & 269.66 & 265.66 & 225 & 201 \\
\hline $\begin{array}{c}\text { Diabetic + Methanolic } \\
\text { Extract (300mg/kg) }\end{array}$ & 193.33 & 182.66 & 186 & 187 & 168.66 \\
\hline
\end{tabular}




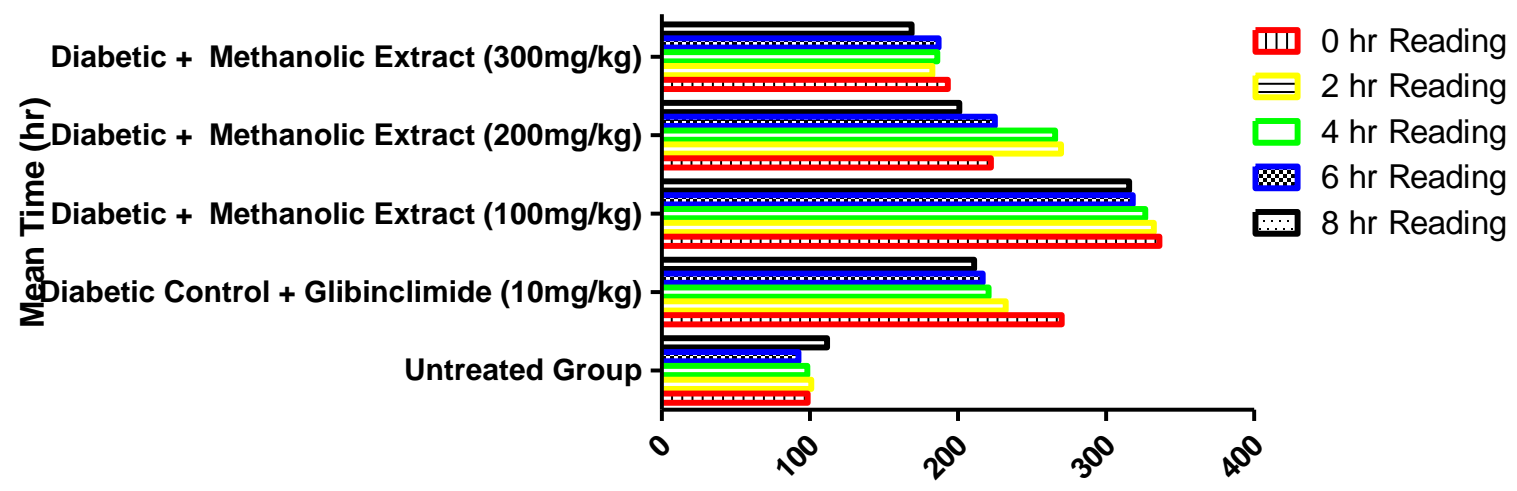

Mean Fasting Blood Sugar $(\mathrm{mg} / \mathrm{kg})$

Figure 1. Blood glucose level of Rabbits

Group C was kept on vigna radiata plant's extract at dosage of $100 \mathrm{mg} / \mathrm{dl}$ for continuous $8 \mathrm{hrs}$ at the interim of zero hrs, $2 \mathrm{hrs}, 4 \mathrm{hrs}$, $6 \mathrm{hrs}$ and $8 \mathrm{hrs}$. At the last of the process of treatment, the glucose, triglyceride and cholesterol level of Group C was recorded as $315.66 \mathrm{mg} / \mathrm{dl}, 85 \mathrm{mg} / \mathrm{dl}$, and $203.33 \mathrm{mg} / \mathrm{dl}$ respectively (Table $2 \&$ Fig. 2).

Table 2. Blood triglyceride level (mg/kg) in alloxan induced diabetic rabbits

\begin{tabular}{|c|c|c|c|c|c|}
\hline & $\begin{array}{c}\mathbf{0 ~ h r} \\
\text { Reading }\end{array}$ & $\begin{array}{c}\mathbf{2} \mathbf{~ h r} \\
\text { Reading }\end{array}$ & $\begin{array}{c}\mathbf{4} \text { hr } \\
\text { Reading }\end{array}$ & $\begin{array}{c}\mathbf{6} \mathbf{~ h r} \\
\text { Reading }\end{array}$ & $\begin{array}{c}\mathbf{8 ~ h r} \\
\text { Reading }\end{array}$ \\
\hline Untreated Group & 66 & 66.33 & 68.33 & 71 & 70 \\
\hline $\begin{array}{c}\text { Diabetic Control + } \\
\text { Glibenclimide (10mg/kg) }\end{array}$ & 84 & 85.66 & 93.33 & 98 & 95 \\
\hline $\begin{array}{c}\text { Diabetic + Methanolic } \\
\text { Extract (100mg/kg) }\end{array}$ & 81 & 85.66 & 87.33 & 85 & 85 \\
\hline $\begin{array}{c}\text { Diabetic + Methanolic } \\
\text { Extract (200mg/kg) }\end{array}$ & 78 & 76.33 & 74 & 76 & 78 \\
\hline $\begin{array}{c}\text { Diabetic + Methanolic } \\
\text { Extract (300mg/kg) }\end{array}$ & 74.66 & 75.66 & 75.66 & 76 & 72.33 \\
\hline
\end{tabular}

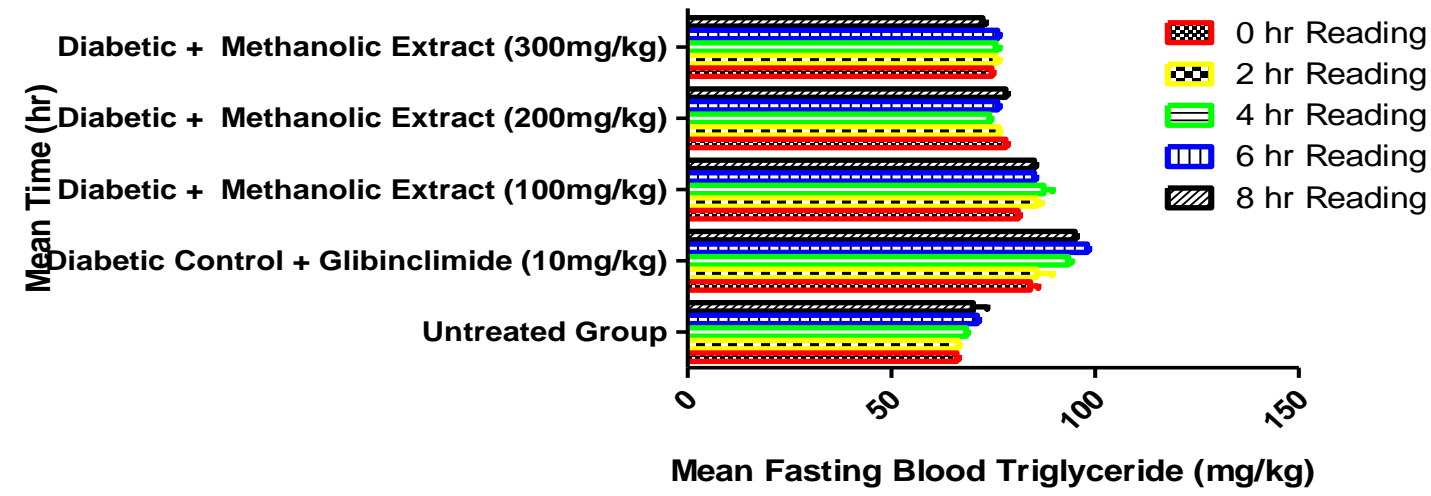

Figure 2. Blood triglyceride level of Rabbits 
Group D was treated with plant extract of vigna radiata at dosage of $200 \mathrm{mg} / \mathrm{kg}$ for continuous $8 \mathrm{hrs}$ at the interim of zero hrs, 2 hrs, $4 \mathrm{hrs}, 6 \mathrm{hrs}$ and $8 \mathrm{hrs}$. At the last of the process of treatment, the glucose level, triglyceride and cholesterol of Group D was recorded as $201 \mathrm{mg} / \mathrm{dl}, 78 \mathrm{mg} / \mathrm{dl}$, and 188.33 $\mathrm{mg} / \mathrm{dl}$ respectively (Table $3 \&$ Fig. 3 ).

Table 3. Blood cholesterol level $(\mathrm{mg} / \mathrm{kg})$ in alloxan induced diabetic rabbits

\begin{tabular}{|c|c|c|c|c|c|}
\hline & $\begin{array}{c}\mathbf{0 ~ h r} \\
\text { Reading }\end{array}$ & $\begin{array}{c}\mathbf{2} \text { hr } \\
\text { Reading }\end{array}$ & $\begin{array}{c}\mathbf{4} \text { hr } \\
\text { Reading }\end{array}$ & $\begin{array}{c}\mathbf{6 ~ h r} \\
\text { Reading }\end{array}$ & $\begin{array}{c}\mathbf{8} \text { hr } \\
\text { Reading }\end{array}$ \\
\hline Untreated Group & 103.33 & 106.33 & 109 & 105 & 103 \\
\hline $\begin{array}{c}\text { Diabetic Control + } \\
\text { Glibenclimide (10mg/kg) }\end{array}$ & 211.33 & 215.33 & 211.33 & 214 & 214.66 \\
\hline $\begin{array}{c}\text { Diabetic + Methanolic Extract } \\
(100 \mathrm{mg} / \mathrm{kg})\end{array}$ & 202.33 & 203.33 & 207 & 204.33 & 203.33 \\
\hline $\begin{array}{c}\text { Diabetic + Methanolic Extract } \\
(200 \mathrm{mg} / \mathrm{kg})\end{array}$ & 187 & 190.33 & 185 & 183.33 & 188.33 \\
\hline $\begin{array}{c}\text { Diabetic + Methanolic Extract } \\
(300 \mathrm{mg} / \mathrm{kg})\end{array}$ & 166 & 165.33 & 163.33 & 162 & 154 \\
\hline
\end{tabular}

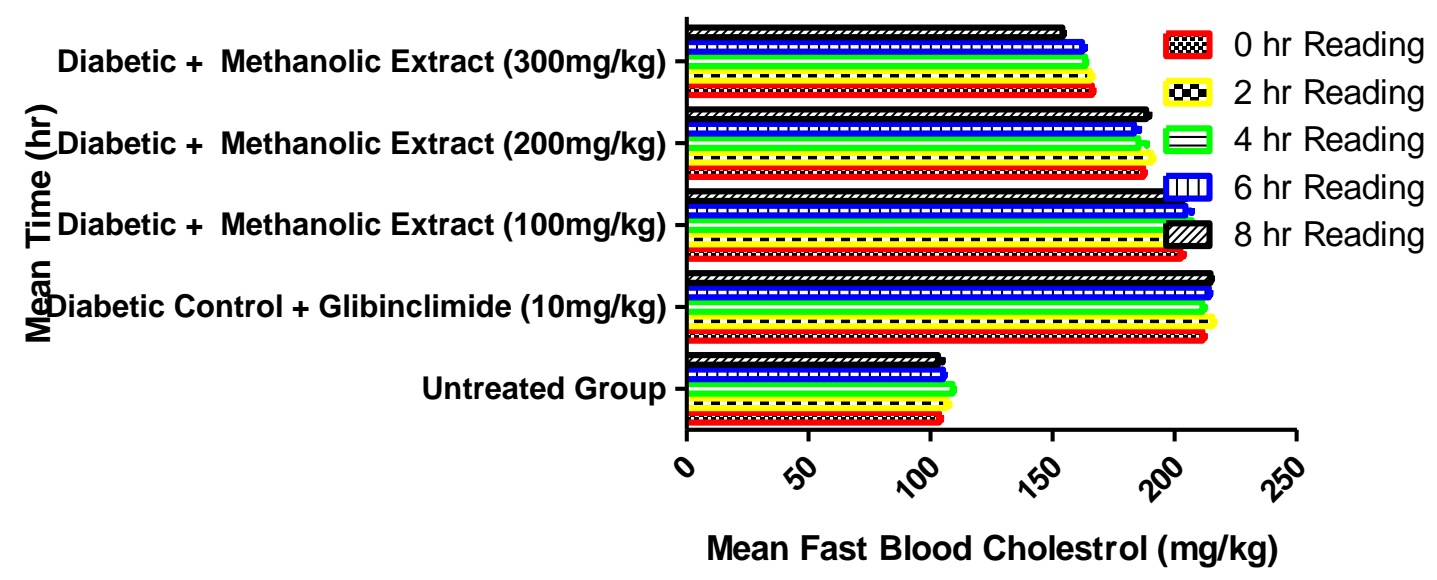

Figure 3. Blood cholesterol level of Rabbits

Group E was treated with plant extract at the dose rate of $300 \mathrm{mg} / \mathrm{dl}$ for regular $8 \mathrm{hrs}$. It was given at the interval of zero hrs, $2 \mathrm{hrs}, 4$ hrs, $6 \mathrm{hrs}$ and $8 \mathrm{hrs}$. At the last of the process of treatment, the glucose, triglyceride and cholesterol level of Group E was recorded as $168.66 \mathrm{mg} / \mathrm{dl}, 72.33 \mathrm{mg} / \mathrm{dl}$ and $154 \mathrm{mg} / \mathrm{dl}$ respectively.

\section{Discussion}

Diabetus mellitus is increasing worldwide due to repeation of cousin merriageship due to lack of actual genetic knowledge. This is the third cause of death after cancer [4]. The current remedies for the cure of diabetes have adverse effects on human health. Therefore there is a need to carry out research on the derivatives of the plant components which do not possess adverse or side effects. So in this regard hypoglycemic impacts of Vigna radiata have been assessed in the present investigation. The results of the research show that methanolic extract of Vigna radiata delivered critical decrease in level of blood glucose with the increase of dosages. The findings additionally revealed that the antidiabetic property of the Vigna radiata extract expanded with time, as maximal impact was accomplished at the eighth hours 
of plant extract administration. This reflects that the constituents which are active in the plant extract of Vigna radiata require time to spread at the target site. This pattern has been observed in other plants with antidiabetic property Sharma et al., [5]. The Vigna radiata extract lowered the elevated sugar level of blood in alloxan-induced diabetic rabbits. The dose rate of 200 and $300 \mathrm{mg} / \mathrm{kg}$ treatment, when compared with Glibenclimide $10 \mathrm{mg} / \mathrm{kg}$ treatment disclosed the effect. The plant extract indicated quicker activity than the standard used medicine. The findings are in full confirmation with the results of Khatune et al. [6] who concluded antidiabetic properties of ethanol concentrate of Grewia asiatica Linn. by using bark in alloxan-initiated diabetic rodents. The Vigna radiata treatment at dosage of $300 \mathrm{mg} / \mathrm{kg}$, when matched with the Glibinclimide $10 \mathrm{mg} / \mathrm{kg}$ treatment group, the triglyceride (TG) levels were in normal range. The serum level of triglycerides was significantly decreased when treated with the extracts of Vigna radiata as compared to the Glibenclimide $10 \mathrm{mg} / \mathrm{kg}$ treatment group. Our outcomes were as per results of Erukainure et al. [7] which indicated the extract of Clerodendrum volubile $\mathrm{P}$ Beauv (Labiate) having anti-dyslipidemic property. The extract of Vigna radiata reduced significantly triglyceride levels. This impact may be because of rise in endothelium bound lipoprotein lipase. This controls transfer of lipids within the body by Taskinen [8]. Alloxan monohydrate damaged pancreatic $\beta$ cells when induced in the experimental rabbits. However when the extract of Vigna radiata was given orally the normal population size of islets was resotored by the regeneration of $\beta$-cells. The comparison of glibenclimide treated group and extract treated group of rabbits indicated decrease in cholesterol level in the blood. When all the groups treated with plant extract contrasted the glibenclimide $10 \mathrm{mg} / \mathrm{kg}$ treatment group demonstrated a significant decrease in cholesterol level. This revealed the positive effect of Vigna radiata in treatment of diabetus. Tachibana et al. [9] stated that protein in mung bean demonstrated hypoglycemic and hypolipidemic property in experimental rats. This suggests that with favorable amino acid sequence and composition, dietary proteins are capable to decrease the serum cholesterol level in experimental rats.

\section{Conclusion}

As a result of this study it was confirmed that Vigna radiata has the ability to reduce the level of glucose in blood. It was further exposed that the plant extract of Vigna radiata has also its duel effect on controlling of cholesterol, triglyceride and total protein.

\section{Authors' contributions}

Conceived and designed the experiments: $\mathrm{R}$ Bilqees \& M Romman, Performed the experiments: R Bilqees \& $\mathrm{M}$ Romman, Analyzed the data: M Romman, Contributed reagents/ materials/ analysis tools: $\mathrm{M}$ Subhan, S Jan, R Parvez, M Adnan, M Ikram \& S Iqbal, Wrote the paper: R Bilqees \& M Romman.

\section{Acknowledgement}

We acknowledge Pharmacognosy Laboratory, Department of Botany, University of Chitral for the provision of space for this research.

\section{Reference}

1. Sivaraj A, Devi K, Palani S, Vinoth kumar P, Senthil Kumar B \& David E (2009). Anti-hyperglycemic and Antihyperlipidemic effect of combined plant extract of Cassia auriculata and Aegle marmelos in streptozotocin (STZ) induced diabetic albino rats. Inter J of Pharm Tech Res 1: 1010-1016.

2. Haq A. (1989). Studies on the yield and related morphological characters of some new mungbean genotypes in irrigated environment. M.Sc. Thesis. Dept. Agronomy, Univ. 
3. Tang D, Dong Y, Ren H, Li L \& He C (2014). A review of phytochemistry, metabolite changes, and medicinal uses of the common food mung bean and its sprouts (Vigna radiata). Chem Central J 8: 4.

4. Alarcon-Aguilar F, Jimenez-Estrada M, Reyes-Chilpa R \& Roman-Ramos R (2000). Hypoglycemic effect of extracts and fractions from Psacalium decompositum in healthy and alloxandiabetic mice. $J$ of Ethnopharmacol 72: 21-27.

5. Sharma SB, Nasir A, Prabhu KM \& Murthy PS (2006). Antihyperglycemic effect of the fruit-pulp of Eugenia jambolana in experimental diabetes mellitus. J Ethnopharmacol 104: 367373.

6. Khatune NA, Rahman BM, Barman RK \& Wahed MI (2016). Antidiabetic, antihyperlipidemic and antioxidant properties of ethanol extract of Grewia asiatica Linn. bark in alloxan-induced diabetic rats. BMC Comple and Alternative Med 16.

7. Erukainure OL, Hafizur RM, Kabir N, Choudhary MI, Atolani O, Banerjee P \& Islam MS (2018). Suppressive Effects of Clerodendrum volubile $\mathrm{P}$ Beauv. [Labiatae] Methanolic Extract and Its Fractions on Type 2 Diabetes and Its Complications. Frontiers in Pharmacol 9.

8. Taskinen, M (1987). Lipoprotein lipase in diabetes. Diabetes/Metabolism Rev 3: 551-570.

9. Tachibana N, Wanezaki S, Nagata M \& Motoyama $T$ (2013). Intake of mung bean protein isolate reduces plasma triglyceride level in rats. Func Foods in Health and Dis 3: 365-376. 